Ook het Accountantsfonds had zijn belangstelling; in 1939/40 werd hij lid van de $R$ aad van Beheer van dat fonds. $Z_{i j n}$ verdiensten voor het Instituut werden in 1947 exkend, toen de ledenvergadering hem op voordracht van het Bestuur tot Lid van Verdienste benoemde.

Echter ging zijn belangstelling reeds vele jaren uit naar de academische opleiding voor het accountants-beroep. In April 1926 werd hij benoemd tot lector aan de Economische Hogeschool in Rotterdam. In die functie heeft hij een belangrijk aandeel gehad in de opleiding van academisch gevormde accountants, in de laatste jaren als buitengewoon hoogleraar; als zodanig werd hij in 1945 benoemd.

De wetenschap, dat de herinnering aan en de invloed van zijn werk nog vele jaren in accountantskringen zal blijven leven, moge zijn nabestaanden tot troost zijn.

\title{
IN MEMORIAM C. A. BLAZER.
}

Op 8 November j.1. is plotseling overleden collega C. A. Blazer, buitengewoon hoogleraar in de accountancy aan de Nederlandse Economische Hogeschool in Rotterdam.

Blazer heeft voor de ontwikkeling van het accountantsberoep in $\mathrm{Ne}$ derland grote verdiensten gehad. Sedert 1910 lid van het Nederlands Instituut van Accountants, had hij in verschillende functies een werkzaam aandeel in de opleiding voor en de algemene leiding van dit beroep; hij was gedurende een reeks van jaren lid van het Bureau der Examens, en vele jaren ook van het Bestuur, in zijn laatste bestuursperiode als plaatsvervangend voorzitter, terwijl hij in verschillende Raden en Commissies van het N.I.v.A. zitting heeft gehad.

Het is niet ieder in de accountantskring gegeven, om in het beroep een vrijwel rechte lijn te volgen; tal van invloeden kunnen ten gevolge hebben. dat de curve voor het praktische werk min of meer grillig wordt en de doelstellingen voor de arbeid wisselen. Zo ook voor deze betreurde overledene. Vele jaren was hij werkzaam bij enkele grote bankinstellingen in Nederland; enkele malen heeft hij deze arbeid verwisseld voor de praktijk van public-accountant, laatstelijk als lid van de bekende Accountants-associatie Klijnveld. Kraayenhof en Blazer. Van hem kan worden getuigd, dat hij er in elke hem opgelegde taak in is geslaagd, een vooraanstaande positie in te nemen; erkend is zijn autoriteit, niet alleen in het accountantsberoep, doch ook in de interne accountantsdiensten van het bankbedrijf, waar hij onder meer grote verdiensten heeft gehad op het gebied der mechanisering van de bankadministratie en van de verstevigina der interne contrōle in dit veel omvattende bedrijf.

Maar het zwaartepunt moet hier toch worden gelegd op het belangrijke aandeel, dat hij in de verzorging van de opleiding voor het accountantsberoep heeft gehad, in het bijzonder bij de Economische Hogeschool, waar hij, eerst als lector en gedurende de laatste jaren als buitengewoon hoogleraar. deze Instelling krachtig heeft gesteund in haar lofwaardig streven, om de beroepsopleiding meer en meer te brengen in de sfeer van het Hoger Onderwijs. Behalve naar het grote leed, dat het plotseling verscheiden van deze hun zo dierbare dode moet hebben gebracht voor de nabestaanden, die in hem de altijd vaardige, krachtige en moeilijk vervanqbare familie-leider zullen betreuren, gaan de gedachten hier als vanzelf uit naar de Hogeschool, voor welke het in ontstellend kort tijds- 
bestek heengaan van het drietal Polak-Dijker-Blazer, hetwelk op de ontwikkeling van het onderwijs in de accountancy van zo grote invloed is geweest, een welhaast onherstelbare leemte moet betekenen.

Moge het Blazer's nabestaanden tot troost strekken, dat talrijken van onze kring de herinnering bewaren aan hem als een bekwaam, hulpvaardig collega, wiens noeste arbeid het accountantsberoep in vele opzichten ten goede is gekomen.

\title{
DE ACCOUNTANT-AMBTENAAR EN DE OVERHEIDSVOOR- SCHRIFTEN MET BETREKKING TOT DE GEHEIMHOUDING
}

\author{
door Drs L. J. M. Roozen
}

Vier prae-adviezen zijn gepubliceerd, die zich bezig houden met „een bijzondere zijde van het vraagstuk (van de geheimhouding) ...... de vraag, of de regelen, welke naar de algemeen voorgestane opvatting omtrent zwijgplicht en zwijgrecht in het vrije beroep gelden, ook toepassing kunnen en mogen vinden op de accountants in overheidsdienst". 1)

Schrijver dezes meent, dat geen van de prae-adviseurs heeft aangetoond, dat deze zijde van het vraagstuk der geheimhouding werkelijk een principieel eigen inhoud heeft. Slechts één van hen (de heer Sanders) heeft de noodzakelijkheid van dit bewijs ingezien en heeft getracht het te leveren. Hij heeft daar echter naar schrijvers overtuiging in gefaald.

Ziehier waarom.

De vraag valt in tweeën uiteen:

a. Zijn de beginselen, welke naar het wezen van de functie van de accountant-ambtenaar de inhoud van diens zwijgplicht en zwijgrecht bepalen, dezelfde als voor de accountant in het vrije beroep?

b. Welke positieve overheidsvoorschriften beïnvloeden de concrete inhoud van zwijgplicht en zwijgrecht van de accountant-ambtenaar op een zeker moment?

De behandeling van de tweede vraag is alleen van practische betekenis, indien de eerste vraag bevestigend moet worden beantwoord (hetgeen niet het geval zal blijken te zijn).

Voorts mag in geen geval voor de bewijsvoering bij de eerste vraag, een beroep worden gedaan op positieve voorschriften. Hieraan maken drie prae-adviseurs zich schuldig.

Enkele voorbeelden.

De heer De Blaey, die wil bewijzen, dat ,.t vraagstuk" voor twee door hem onderscheiden groepen van overheidsaccountants .,geheel anders ligt", zegt: "Duidelijk wordt dit als we de voorschriften nagaan”, waarna in zijn betoog het "hoe" het „,waarom" vervangt. 2)

Collega Drs Lindner voert geen enkel beginsel aan. Zijn mening, dat ,er verschil bestaat in zwijgplicht tussen de public-accountant en de ambtenaar-accountant" volgt volgens hem uit de omstandigheid, dat .,de zwijgplicht van de ambtenaar-accountant vast (ligt) in tal van besluiten

1) Aldus de formulering door de redactie van het M.A.B. in No, 6/1948 blz. 166.

2) M.A.B. No. 6/1948 blz. 169.

m a b blz. 300 